\title{
Comparing Critical Capitalist Commodity Chains in the Early Twenty-first Century: Opportunities For and Constraints on Labor and Political Movements ${ }^{1}$
}

\author{
Elizabeth Sowers \\ CSU-Channel Islands \\ elizabeth.sowers@esuci.edu \\ Paul S. Ciccantell \\ Western Michigan University \\ David A. Smith \\ Univ. of California-Irvine
}

\begin{abstract}
There have been a number of critical historical opportunities for labor to exert power by interrupting long distance flows of commodities at the extraction, processing, and transport stages. This vulnerability has been used by workers in these industries to gain higher wages and better working conditions and to achieve political goals in national and international arenas. In this paper, we compare two commodity chains that are critical components of the global economy. The first, which we describe as transport, is a broad category involving a range of manufactured goods, whose delivery to customers around the world was fundamentally changed in the past fifty years via "containerization" and "the logistics revolution." The second is oil and gas, which also has experienced recently dramatic changes in both extraction (via "tar sands" and "fracking") and transportation. In each case, we discuss possibilities and challenges for labor and political organizing to disrupt capital in these key commodity chains. We identify the "stakes" in each commodity chain by demonstrating the vulnerabilities on which labor and political organizations/movements could capitalize, which usually stem from the capital intensity and global integration of each critical commodity chain. These vulnerabilities are the factors which form the most basic opportunities for organizing in these sectors. Our analysis further suggests that while transport and raw materials remain vulnerable nodes in capitalist commodity chains, there are also constraints and challenges to be faced by labor and social movement organizations (SMOs) that might attempt to leverage power over these circuits of the worldeconomy.
\end{abstract}

Keywords: New historical materialism, environmental activism, labor unions, logistics, oil and gas extraction

\footnotetext{
${ }^{1}$ Special thanks to $J W S R$ special issue editor, Jennifer Bair for extensive criticisms and suggestions on an earlier draft.
} 


\section{Journal of World-Systems Research}

There are a number of instances in the past when labor used opportunities to interrupt long distance flows of commodities at the extraction, processing, and transport stages. This vulnerability was sometimes successfully exploited by workers to gain higher wages and better working conditions or to achieve other political goals. Australian coal miners, railroad workers, and dockworkers repeatedly gained higher wages and benefits by leveraging their role in facilitating (or impeding) coal exports to Japan during the 1960s and 1970s (Bunker and Ciccantell 2007), while the 1934 West Coast Longshoremen's Strike led to the unionization of all West Coast ports and set in motion a long period of rising wages for workers in this industry (Selvin 1996). In these and many other instances, workers at key chokepoints of critical global commodity chains seized opportunities to gain significant benefits for themselves. In an earlier paper (Ciccantell et al. 2012), we began an examination of the opportunities for and constraints on efforts by labor and other organizations to take advantage of these vulnerabilities in commodity chains, focusing particularly on containerized manufactured goods, coal, and iron ore, and on how these commodity chains are affected by potential conflicts in these industries resulting from growing hegemonic rivalries.

We build on our earlier analysis by comparing two particularly important commodity chains in the contemporary global economy and discussing possibilities and challenges for labor and political organizing to disrupt capital in these key chains. The first is what we conceive as the transport chain, which involves a range of manufactured goods whose delivery to customers around the world was fundamentally changed in the past fifty years via "containerization" and "the logistics revolution." In effect, this network of links underlies all the other "globalized" commodity chains that now increasingly dominate the sinews of the world-economy in an era of pervasive "outsourcing" and internationalization of various types of production. The second is oil and gas, which also has experienced recently dramatic changes in both extraction (via "tar sands" and "fracking") and transportation (in more increasingly extensive pipeline infrastructure and larger "tankers" on both land and sea). Contemporary urban-industrial societies are extremely dependent, of course, on these fossil fuels - indeed, oil and gas are the literal "fuel," not only of most agriculture, extraction and manufacturing, but also of the crucial logistics chain introduced above.

With our focus on opportunities and constraints on various types of organizing/"resistance" to corporate power, here we attempt to identify the "stakes" in each commodity chain by demonstrating the vulnerabilities and points of weakness. There are nodes or links in these chains that are particularly conducive for the efforts of labor, social movement organization (SMOs) and other political activists to disrupt critical flows. These vulnerabilities often arise in globally integrated commodity chains where there are crucial nodes of physically concentrated and/or capital intensive production. Such nodes constitute chokepoints in the circuits of global capitalism over which activists may be able to gain leverage. We also note some salient differences between the specific opportunities and constraints in these chains for workers as opposed to other kinds of activists (for example, environmental activists mobilizing $v i s-\grave{a}$-vis oil and gas mining and, especially, the transport of these materials). As such, we identify key factors within each commodity chain that pose challenges to organizing efforts. Our analysis culminates in an overall assessment of whether or not the contemporary moment is one where labor or other popular groups can capitalize on interrupting flows of commerce at points of extraction, processing, or transportation, and we suggest some directions for future research.

In the following section, we provide an overview of the theoretical model and empirical methods employed in our analysis, as well as a brief discussion of key findings from our earlier 
work. In the third section, we examine key aspects of the global logistics industry that are particularly relevant for labor and political movements, building from our analysis of containerization into a more general consideration of the development of the Third Party Logistics (3PL) industry. In the fourth section, we turn our attention to another critical commodity chain, the oil and gas industry, focusing on a growing trend toward North American energy independence and the potential deconstruction of the global commodity chains that have long characterized this industry. Then, we compare these two commodity chains in terms of their opportunities and constraints for activists.

\section{Theory and Methods for Comparative Analysis of Global Commodity Chains}

Our theoretical model of comparative global commodity chains brings together the global commodity chains literature from the world-systems tradition (Hopkins and Wallerstein 1982; Gereffi, Korzeniewicz and Korzeniewicz 1994) with new historical materialism (Bunker and Ciccantell 2005, 2007) to examine what we term "lengthened" commodity chains. It reworks the global commodity chains approach in four ways. First, beginning our analysis with primary products forces the examination of various modes, techniques and technologies of extractive regimes, as well as of the key role of transportation systems that move these often heavy, bulky materials from remote agricultural and mining locales to urban and metropolitan places where manufacturing and consumption take place. Second, focusing on this "longer chain" raises new questions about spatially-based disarticulations and contestations over the shape of the future of the capitalist world-economy. Starting at the beginning of a commodity chain not only provides a more comprehensive and complete story of contested transformation sequences, but it also reveals new ways in which geographic and spatial disarticulation and inequalities are integral to the global economy. Third, we explicitly focus on tightly integrated social and natural processes across a wide range of industries. Our analysis allows us to make comparisons across industries and over decades (potentially even centuries) in our effort to understand the relationship between society and nature and long term change in the capitalist world-economy. Fourth, by grounding our comparative analysis in the material and social characteristics of global commodity chains, we are able to identify both opportunities for and constraints on the efforts of labor and political organizations to find nodes in these commodity chains in which they can gain leverage to achieve their goals (Ciccantell and Smith 2009a, 2009b; Ciccantell, Smith and Doyon 2010).

\section{Global Commodity Chains}

In the foundational work on global commodity chains in world-systems literature, Hopkins and Wallerstein define a commodity chain as "a network of labor and production processes whose end result is a finished commodity" (1982:159). In its initial formulation, this analytic approach sought to link mining, logging, agriculture, and other forms of raw materials extraction from nature, typically in the periphery, to the industrial processing and consumption of these materials, most commonly in the core, in order to understand the mechanisms that created and reproduced systematic inequalities in the capitalist world-economy (Hopkins and Wallerstein 1982). This approach brought together analysis of the impoverishment of extractive peripheries, their economic and political connections to the core that enriched the core, and incorporated an explicit focus on consumption, particularly of final consumer goods, into world-systems analysis. 


\section{Journal of World-Systems Research}

Building on this initial work, Gereffi, Korzeniewicz and Korzeniewicz (1994) defined a global commodity chain as "sets of interorganizational networks clustered around one commodity or product, linking households, enterprises and states to one another within the world-economy...(it is) the sequential stages of input acquisition, manufacturing, distribution, marketing and consumption" (1994:2). Their work and that of others who used this global commodity chains (GCC) approach examined key processes of change in the capitalist worldeconomy in the late twentieth century including how and where surplus or profit accrues in points where commodity chains touch down. They also explored whether "industrial upgrading," a popular policy prescription in the periphery and semiperiphery, was possible at different nodes in the chain. Studies of "upgrading" looked for evidence that actors could increase the value of local transformation, capture more of the surplus/profits from the chain, and ultimately promote economic development. Many studies in this tradition (Gereffi 1994, Appelbaum, Smith and Christerson 1994; Bair and Gereffi 2001; Gereffi and Memdovic 2003; Schrank 2004; O'Riain 2004; Bair 2005) focused on the efforts of non-core nations to industrialize based on textiles, electronics, and other consumer goods manufactured for sale in core markets. This research yielded valuable insight into contemporary globalization, development policies, firm strategies, and the evolution of the world economy in the late twentieth century.

The GCC model provides an excellent tool for examining "development" and how production and consumption vary across natural and social space. How and where do GCCs "touch down" around the world? How do GCCs affect local people and places? The fundamental insight of GCC analysis, that industries should be analyzed as a linked set of activities that often cross multiple national boundaries in a globalized economy, became an integral part of international management standards, such as the ISO 14001 standards, life-cycle assessment models, and supply chain management (ISO 2006). The prevailing focus on consumer goods industries meant, however, that analysis of the upstream end of the chain in raw materials extraction and processing received much less attention.

More recent work in this tradition introduces the theoretical concept of disarticulations into global commodity chains (Bair and Werner 2011; Bair 2005). While the GCCs literature often took for granted that, once established, commodity chains would continue to exist, Bair and Werner emphasize the frequency of disarticulations of these chains, or how particular activities and places are incorporated, maintained, and then removed from these chains. As we will discuss in the section on the oil and gas industry in North America, this concept of disarticulation opens the door for understanding how global commodity chains may be changed, disrupted, or even consciously deconstructed in support of firm, state, geopolitical, labor, or even social movement interests.

\section{New Historical Materialism}

In contrast to the GCC approach, new historical materialism (Bunker and Ciccantell 2005, 2007) focuses attention on the upstream end of the commodity chain, highlighting the critical role of raw materials extraction, processing and transport in shaping the evolution of the capitalist world-economy. In any rising economy, strategies for economic ascent must respond to and take advantage of contemporary technological, geopolitical, environmental, and market conditions in the rest of the world and of the nation's position and location within that particular historical moment in the evolution of the world-system. These strategies employed by the state and firms in a rising economy must also coordinate the physical characteristics and location in space and in 
topography of the various raw material resources actually or potentially available with the rest of the national territory. The beginnings of economic ascent require successful coordination of domestic technological advances, particularly in heavy industry and transport in a rising economy, with the external solution of access to cheap and steady sources of the raw materials used for heavy industry. The raw materials used in greatest volume present the greatest challenge and best opportunity for economies of scale. These economies of scale, however, drive a contradictory increase in transport cost, as the closest reserves of raw materials are depleted more rapidly as the scale of their industrial transformation increases (see Bunker and Ciccantell 2005 for an extended discussion).

The tension of this contradiction between the economies of scale and the cost of space foments technological innovation in transport and in chemical and mechanical means of reducing component inputs per unit of output. It also encourages improvements in the control of heat, pressure and the mixes of chemicals that make the unit material inputs stronger, and thus enable smaller, lighter amounts to perform the same work. All of these technological fixes drive each other, and they all tend to generate increases of scale, thus exacerbating over the long term the very contradiction between scale and space that they are designed to solve (Bunker and Ciccantell 2005).

The national economies that most successfully initiated technological and organizational solutions to this contradiction simultaneously generated their own rise to economic dominance, restructured the mechanisms and dynamics of systemic and hierarchic accumulation, and expanded and intensified the commercial arena of raw materials trade and transport. Solving the raw materials problem - the tension between increasing economies of scale in raw materials extraction and transport and the accompanying diseconomies of the increasing cost of space-is daunting. It requires the coordination of multiple physical and social processes across geopolitical and physical space with domestic relations between firms, sectors, the state, labor, and new technologies. Rising economies resolve these problems at the same time as, or even before, they increase industrial competitiveness. These solutions stimulate complex processes of learning and of institutional change that fundamentally mould the organization of the national economy at the same time that they change international markets and the rules binding participants in them (Bunker and Ciccantell 2005).

The challenges and the opportunities presented by the basic raw materials industries and by the transport systems on which they depend foster generative sectors. These sectors, beyond creating the backward and forward linkages that underlie the concept of a leading sector, also 1) stimulate a broad range of technical skills and learning along with formal institutions designed and funded to promote them; 2) contribute to vast and diversified instrumental knowledge held by interdependent specialists about the rest of the world; 3) produce financial institutions adapted to the requirements of large sunk costs in a variety of social and political contexts; 4) lead to specific formal and informal relations between firms, sectors, and states; and, 5) shape the form of legal distinctions between public and private and between different levels of public jurisdiction (Bunker and Ciccantell 2005).

Generative sectors are more numerous, more easily observed, and more efficacious in those national economies that are growing so rapidly that they must achieve massive increases in throughput and transformation of raw materials. In an established hegemon, rates of economic growth are slower and therefore demand for raw materials grows more slowly; this in turn means that an industry that serves as a generative sector in a rising economy (e.g. steel in the United States and Germany in the late 19th century) has far less impact in a more slowly growing 


\section{Journal of World-Systems Research}

hegemon (in that period, Great Britain) (Bunker and Ciccantell 2005). The concept is relational, however, within a world-systems perspective, and thus implies that generative sectors in a rising economy will have significant consequences for other economies that export raw materials or trade in other kinds of goods (Bunker and Ciccantell 2005).

Generative sectors are not necessarily those in which profits are highest, even though high profit sectors (whether gold and silver in the seventeenth century or computer technology in the twentieth century) are those that typically attract the most analytical attention (see, e.g., Arrighi 1994; O'Hearn 2001). Instead, generative sectors provide the material building blocks, cost reductions across many sectors to increase competitiveness, and patterns of state-sector-firm relations and other institutions that combine to drive economic growth and ascent. They become the "drivers" of economic development, with spin-off effects on other parts of the economy. Generative sectors incorporate a much broader range of linkages and thus have impacts that are more significant and farther reaching than the examples of putative "industrial upgrading" emphasized by Gereffi and his colleagues and other commodity chain scholars. Rather than simply adding a stage or two of processing to a labor intensive manufacturing process or one additional stage of processing of a raw material into a more concentrated form, generative sectors form lengthened chains that link raw materials through technology and capital intensive processing to the sale of final products in the leading industries of a particular systemic cycle of accumulation.

How can rapidly growing economies acquire the raw materials essential to sustain these generative sectors, particularly in the face of domestic raw materials depletion and the resulting diseconomies of space, as these raw materials must be brought from more distant areas outside the political control of the ascendant state? One critical strategy to accomplish this task has been to wrest control of raw material-producing peripheries from earlier ascendant economies via direct corporate investment in extraction, the creation of new forms of transportation or energy infrastructure to monopolize processing or export, or, in some cases, "old-fashioned" colonialism via political control. This strategy is tantamount to "theft" of these extractive peripheries, since another power had already undertaken the difficult and expensive tasks of building the necessary infrastructure, creating political, organizational, and legal forms that promote international trade and investment relations between a particular raw materials-producing state and the world economy, and incorporating these peripheries economically and politically into the world economy. Earlier processes of economic ascent progressively globalized the world economy and brought new raw materials peripheries into the global trading system to supply the earlier ascendants' industries, so new ascendant economies and states can initially purchase raw materials from this established supply system (Ciccantell 2009). In this sense, the role of the rising economy might be described as "stealing" these raw materials peripheries from earlier ascendants by redirecting their raw materials exports away from those economies that fomented the creation of this exporting capacity, and toward itself and its rapidly growing need for raw materials.

The newer ascendants' rapid growth, however, means that their demand is increasing dramatically, necessitating a substantial increase in supply if these growth rates are to be sustained. The combination of the existing social and material infrastructures in the raw materials peripheries established by earlier ascendants, rapid demand growth in the ascendant economy, and the willingness of the newer ascendant economy to pay higher prices for raw materials in order to sustain their domestic growth creates an opportunity. Higher prices for rapidly increasing volumes of exports (in contrast to slower demand growth in the mature economies of 
earlier ascendants) motivate firms and domestic elites in the periphery - and even existing core powers with fewer opportunities for profitable investments - to invest in production for export to the new ascendant. States in raw materials-exporting regions typically support this investment with subsidies for transport and extraction, both in an effort to promote economic development and in hopes of gaining better returns and more political freedom from the power of the existing hegemon. This is particularly apparent in postcolonial situations in which newly independent states seek to break free from neocolonial ties, and in situations of resource nationalism in which states seek greater control over and benefits from raw materials exports. Firms, elites, and states in raw materials peripheries come to see the new ascendant as a potential ally in their attempts to promote political independence and economic development (Ciccantell 2009).

From the perspective of the new ascendant, building these relationships with existing raw materials peripheries is much less expensive and difficult than creating their own new peripheries. One of the most important benefits is that most of the cost and the risk of expanding extraction and transport are borne by firms and states in the extractive periphery and often by firms from the earlier ascendant. At the same time, these investments in mines and transport systems also often create opportunities for exports of industrial products from the ascendant economy to the periphery to support the development of these extractive industries and for consumption by the owners of and workers in these industries. "Stealing" these peripheries from earlier ascendants thus further enhances the rapid growth of the new ascendant by reducing costs and risks while simultaneously creating significant new opportunities for profit from trade and investment (Ciccantell 2009).

The combination of the GCCs framework with new historical materialism also brings to the forefront the potential for contestation over the creation, maintenance, and disarticulation of lengthened commodity chains. In particular, we identify key historical and current episodes in which particular nodes of these chains can become locations of conflict between capital, states, and labor and political organizations that seek to promote their economic and/or political interests.

\section{Comparative Methods for Studying Lengthened Commodity Chains}

Our analytic approach follows a long tradition in world-systems theory of making multiple comparisons across time and space within the context of an evolving global system (see, e.g., Wallerstein 1974; Chase-Dunn 1989; Arrighi 1994; Bunker and Ciccantell 2005). The GCC approach is often utilized to make comparisons between parts of the same commodity chain in different nations and between different commodity chains (see, e.g., the case studies in Gereffi and Korzeniewicz 1994). We follow this approach, while focusing particular attention on the upstream stages of these GCCs and on their role in the long term evolution of the capitalist world-economy, including their roles in economic and geopolitical competitions. Our analytic strategy also includes making multiple comparisons within one commodity chain over time and between different commodity chains in different industries in order to examine processes of social and environmental change.

Grounding these chains in particular places, times, and natural environments is the critical first step to studying lengthened commodity chains in our analysis. This grounding will then allow us to make comparisons of apparently dissimilar chains. Our first step is thus to focus on particular nodes to examine the developmental, socioeconomic, and environmental 


\section{Journal of World-Systems Research}

consequences of incorporation into these chains, and then to examine these lengthened chains as constitutive of the evolution of the capitalist world-economy by driving long term change. Our analytic method combines quantitative and qualitative data on each GCC and its key nodes along five dimensions: industry characteristics, economic characteristics, social characteristics, natural characteristics, and environmental impacts (see Figure 1).

\section{Figure 1. Key Factors for Five Dimensions of Data on GCCs}

\author{
1. Industry Characteristics \\ Degree of concentration at each stage \\ Integration vs. separation of stages \\ Ease-cost of separating stages \\ Importance of marketing/branding \\ Scale of production \\ How difficult is it to globalize \\ Role of transport \\ Share of transport in total costs \\ Share of labor costs in total costs \\ Capital intensity \\ Technology intensity \\ Profitability \\ Role of information technology/infrastructure \\ Length in space \\ Impacts of labor organization \\ Buyer driven vs. producer driven \\ Technologies employed
}

\section{Economic Characteristics}

Economic sustainability

Employment generation

Backward linkages

Forward linkages

Fiscal linkages

Tax/royalty revenues

Role in capital accumulation

Share of world trade

Contribution to GDP growth

Role as a driver of economic development Actual/potential role as a generative sector Articulation into/disarticulation from $\mathrm{GCC}$ and world economy

\author{
3. Social Characteristics \\ Role of NGOs \\ Role of social movements \\ Social sustainability \\ Degree of domestic integration \\ Differential gendered impacts \\ Differential racial/ethnic impacts \\ Impacts on indigenous groups \\ Impacts on local populations \\ Need for military intervention/protection \\ Degree of conflict/violence \\ Degree of labor organization \\ Political characteristics and history of location
}

\section{Natural Characteristics}

Geographic location

Quality of ore

Chemical composition of ore

Geologic characteristics of deposits

Topographic characteristics of deposits

\section{Environmental Impacts \\ Impacts at each stage \\ Environmental sustainability \\ Energy intensity at each stage}




\section{The Global Logistics Industry}

\section{Containerized Manufactured Goods}

This category of chains, defined by transportation mode rather than the product that is being transported, represents many of the key characteristics that differentiate the world economy of the early twenty-first century from that of earlier eras, and includes commodities such as textiles, shoes, consumer electronics, and toys. These products and industries share a number of characteristics. Their high labor intensity led firms to globalize these industries in search of lower-cost labor. This globalization contributed to a deconsolidation of production stages both spatially and organizationally, creating complex networks of core firms that carry out tasks such as design and marketing, and globally dispersed subcontracting firms that produce the components and finished products under the direction of the core firm. Capital intensity is relatively low, as is the degree of technological sophistication in much of this production. These buyer-driven commodity chains span thousands of miles and rely on sophisticated electronic communications technologies for coordination of just-in-time delivery systems that minimize capital investment and inventory costs for the core firms. These products are easily and cheaply transported thousands of miles in containers and constitute a large and rapidly growing share of global trade in volume and especially in value terms (Bonacich and Wilson 2008; Cudahy 2006; Bair 2009).

The dispersion of global production activities around the world is a development made possible by the advent of containerization, the process through which products are easily and cheaply transported across thousands of miles. These goods can remain in the same metal container throughout all phases of this transportation process, often traveling via a combination of ships, railroads, and trucks, thus minimizing the labor costs associated with loading/unloading at each juncture (Bonacich and Wilson 2008; Cudahy 2006). The import of containerization as a widespread transportation method and a booming industry cannot be overstated. In fact, scholars often emphasize the impact that containerization had on the global economy at large, noting that it "changed the world" by facilitating the expansion of global trade, with far-reaching consequences for workers and consumers all around the world, not simply those working within the transportation industry (Donovan and Bonney 2006; Levinson 2006). Table 1 demonstrates the massive growth of seaborne trade over the past few decades: in 1970, 2,566 million tons traveled internationally by sea, but by 2010 , this figure had risen to over 8,000 million tons.

Table 1. International Seaborne Trade (millions of tons loaded)

\begin{tabular}{lllll}
\hline & \multicolumn{3}{c}{ Other } \\
& Oil & $\begin{array}{l}\text { Main } \\
\text { Bulks }\end{array}$ & $\begin{array}{l}\text { Dry } \\
\text { Cargo }\end{array}$ & Total \\
\hline 1970 & 1442 & 442 & 676 & 2566 \\
1980 & 1871 & 796 & 1037 & 3704 \\
1990 & 1755 & 968 & 1285 & 4008 \\
2000 & 2163 & 1288 & 2533 & 5984 \\
2010 & 2752 & 2333 & 3323 & 8408 \\
\hline
\end{tabular}

Source: UNCTAD 2012: 7. 


\section{Journal of World-Systems Research}

Tables 2 and 3 demonstrate the expansion of the world's container ship capacity as well as cargo traveling by container, respectively. Measured in twenty-foot equivalent units (TEUs), the world's container ship fleet boasted only 16 TEUs in 1965 but over 8,000 TEUs by 2005 and 12,800 TEUs by 2010. Similar increases are evident in containerized cargo figures, which rose from 127 millions of tons in the mid-1980s to 1,134 millions of tons in 2006. Taken together, these data indicate the incredible and sustained increases of global trade in recent decades facilitated by containerization of global trade flows.

Table 2: World Container Ship Capacity

\begin{tabular}{ll}
\hline & $\begin{array}{l}\text { Thousands of TEU Total } \\
\text { Capacity of the World's } \\
\text { Container Fleet }\end{array}$ \\
\hline 1965 & 16 \\
1975 & 366 \\
1985 & 1189 \\
1995 & 2492 \\
2005 & 8116 \\
\hline 2010 & 12800 \\
\hline Source: Stopford 2009: 508; UNCTAD 2011
\end{tabular}

\begin{tabular}{ll}
\multicolumn{2}{l}{ Table 3. Container Cargo } \\
\hline Year & Millions of Tons \\
\hline 1983 & 127 \\
1985 & 160 \\
1990 & 246 \\
1995 & 389 \\
2000 & 628 \\
2005 & 1017 \\
2006 & 1134 \\
\hline Source: Stopford 2009: 516.
\end{tabular}

Containerization also paved the way for what Bonacich and Wilson (2008) refer to as the "Logistics Revolution," which includes the integrated management of transportation, warehousing, and inventory control across an entire supply chain, in an effort to mediate the tension between supply and demand. Containerization and the logistics revolution are so important to the world economy that China and other rapidly growing economies in the periphery and semiperiphery of the capitalist world-economy use these industries as critical sectors in their economic development strategies, often with geopolitical and economic support from the existing hegemon, the United States. Table 4 depicts large increases in the millions of TEUs transported through container trade routes, especially those flowing from the Far East 
(including China) to the West. While East-West and West-East trade routes transported roughly equal amounts of cargo in the mid-1990s, the data from 2000 forward demonstrate that the EastWest trade routes now move much more cargo than the West-East routes, attesting to the importance of China and other countries in the Far East to the world of containerized transport. Although these sectors have limited capacity to generate economic linkages within the producing economies, and are very unlikely to serve as generative sectors, they are key loci for creating employment and generating export revenues.

Table 4. Cargo Flows on East-West Container Trade Routes (Millions of TEUs)

\begin{tabular}{rrrrrrr}
\hline Year & $\begin{array}{r}\text { Far East - N. } \\
\text { America }\end{array}$ & $\begin{array}{r}\text { N. America - } \\
\text { Far East }\end{array}$ & $\begin{array}{r}\text { Far East - } \\
\text { Europe }\end{array}$ & $\begin{array}{r}\text { Europe - Far } \\
\text { East }\end{array}$ & $\begin{array}{r}\text { Europe - N. } \\
\text { America }\end{array}$ & $\begin{array}{r}\text { N. America - } \\
\text { Europe }\end{array}$ \\
\hline 1995 & 3.974 & 3.535 & 2.400 & 2.021 & 1.678 & 1.691 \\
2000 & 7.308 & 3.525 & 4.650 & 2.461 & 2.694 & 1.707 \\
2005 & 11.893 & 4.479 & 9.326 & 4.417 & 3.719 & 1.986 \\
2009 & 10.621 & 6.116 & 11.361 & 5.458 & 2.738 & 2.046 \\
\hline
\end{tabular}

Source: UNCTAD 2012: 23.

Labor organization in the factories producing these goods is typically nonexistent or carefully controlled by the state, despite sometimes extensive and risky efforts by local and international unions to organize workers, making these sectors seem highly unlikely to be points of leverage for labor unions or social movements. However, in the transport mode of containerized goods movement, there are potential opportunities for labor organizations and social movements to take advantage of industry characteristics, most notably global production networks and reliance on just-in-time delivery systems, as Bonacich and Wilson (2008) argue in their analysis of the ports of Los Angeles and Long Beach, two ports that are separated by only a few miles, and together comprise the principal U.S. entrepot for containerized manufactured imports from Asia. A port workers' strike in the early $2000 \mathrm{~s}$ and a disruption of smooth operations due to organizational and technical problems in 2004 illustrate the potential vulnerability of the port nodes of this global containerized shipping system (Bonacich and Wilson 2008). In 2011 the Occupy movement attempted to revise this tactic by seeking to disrupt flows of goods through U.S. port facilities owned or utilized by Wall Street firms linked to the recent financial crisis, though with limited success (Romney, Murphy and Linthicum, 2011) (see below in Conclusion for more on Occupy). But more recently, in 2013, less than 500 dock workers at Hong Kong International Terminal, where a large volume of the U.S.-bound China trade begins its trans-Pacific journey, went on strike and managed to "cripple" the world's third largest port and win significant pay raises (Davies and Noble 2013; McCafferty and Pang 2013). This worker action, which garnered support from both student organizations and pro-democracy politicians in Hong Kong, shows that labor clearly still can exploit these logistic commodity chain vulnerabilities, if conditions are right and there is popular solidarity.

The Hong Kong success notwithstanding, the structure of the workforce in the broader port complexes presents several challenges to those seeking to organize these nodes in the global economy to cause economic disruption. Many different groups of workers participate in transportation work, and they experience varied working conditions and levels of union 


\section{Journal of World-Systems Research}

organization. They are also spatially segregated from each other, all of which is problematic for efforts to unite these workers in a common struggle. Workers at U.S. port complexes can be broadly defined to include those working on the ships transporting containers from other parts of the world, those who work as longshoremen loading and unloading the container ships at the ports, the truck drivers who move unloaded containers from the ports to distribution centers, railroads, or retail centers, the warehouse workers who unload and process container goods for reshipment, as well as other transportation-related jobs. It may be that U.S. port workers who are at the terminus of the trans-Pacific trade, moving and preparing it for transport and distribution to disparate customers across the North American continent may have a bit less power over the flow than the Hong Kong dock workers, who could exercise critical leverage at a major shipping "choke point" for outward bound Chinese cargo

On the one hand, transportation work, as described above, includes the highly paid and heavily unionized longshoremen whose work and wages are heavily protected by an active union presence. On the other hand, transportation work also includes truck drivers, many of whom are independent contractors rather than full-time employees of an actual company, and warehouse workers, many of whom are part-time or temporary workers hired through employment agencies. These two groups of transportation workers receive relatively low wages for their work in addition to being excluded from many unionization efforts (Bonacich and Wilson 2008; Bonacich and de Lara 2009; Monaco and Ritter 2009). It is clear that transportation workers experience distinct working lives, are engaged in different parts of the transportation project, and work in physically distinct environments. This makes organizing at these port nodes a complicated project that must account for the contours of the workforce. All of these characteristics of the transportation chain present challenges for those seeking to capitalize on the vulnerability of the port nodes in the globalized container shipping system. But the potential is certainly significant, if the necessary coordination and cooperation can be achieved between labor organizations representing various groups of workers, the creation of labor organizations to represent currently unorganized sectors linked to containerized transport, and the creation of broader national and international labor and political networks.

\section{Integrated Third Party Logistics (3PL) Firms}

Containerization, the increasing economies of scale of air transportation, the global expansion of communications networks, and the expansion of binational and multinational trade agreements encouraged the creation of firms that specialize in coordinating and moving a growing volume and variety of goods around the world. These Integrated Third Party Logistics (3PL) firms have taken over transportation and management tasks that traditionally were handled within the producing and/or selling firm. Prior to 1980, manufacturers relied on liner shipping, commercial airlines and freight forwarding firms to move their products to distributors and retailers. Over the last three decades, however, 3PL firms took over these roles from many manufacturers, distributors and retailers. This shift began with a few firms, led by UPS, FedEx, and smaller European firms serving local markets, moving very high value packages. As these services expanded and customers recognized their value, the firms began to promote them more aggressively to customers. During the $1990 \mathrm{~s}, 3 \mathrm{PL}$ firms took over a larger and larger share of the movement of manufactured goods, with lower-value goods moving in containers by sea and high-value manufactured products moving by air (Lobo and Zairi 1999a, b, c; Bowen and 
Leinbach 2004, 2006; Hertz and Alfredsson 2003; Klaus 2011; Anderson et al. 2011; Bhatnagar and Viswanathan 2000; Taylor and Hallsworth 2000; Bowen 2012). The volume of high value goods carried by air expanded rapidly, as Table 5 shows.

Table 5. Global Air Shipping Volume (Millions of Ton-Kilometers)
\begin{tabular}{cc} 
Year & Volume \\
\hline 1973 & 15,568 \\
1980 & 26,825 \\
1990 & 56,145 \\
2000 & 118,257 \\
2010 & 189,325 \\
\hline
\end{tabular}

As firms recognized the dramatic economies of scale and speed possible in this industry in the 1990s, a series of mergers and acquisitions, restructurings of existing firms, and a convergence of firm strategies toward providing integrated logistics led to the creation of an increasingly concentrated industry. Four main firms-UPS, FedEx, DHL and TNT-have emerged as the largest global 3PL firms. All four firms have a similar structure of operations, relying on a limited number of hub locations for air transport, warehousing, and further processing for manufacturers. There are a number of smaller firms that continue serving market niches for moving high-value manufactured goods, including commercial airlines, liner shipping, and small and medium size freight forwarders (Lobo and Zairi 1999a, b, c; Bowen and Leinbach 2004, 2006; Hertz and Alfredsson 2003; Klaus 2011; Anderson et al. 2011; Bhatnagar and Viswanathan 2000; Taylor and Hallsworth 2000; Bowen 2012).

In terms of opportunities for labor organization, this sector shows an interesting mixture of conditions. Some firms were unionized years ago (e.g. UPS), while others remain unorganized (e.g. FedEx), despite otherwise very similar structures and operations. These firms are the links in GCCs that span multiple countries and thousands of miles, but this linking role creates some important opportunities for labor and social movement organizations, in part because these logistics jobs are inherently tied to a particular location and cannot be offshored (Sheffi 2012). The large amount of capital invested in the products being carried in each cargo makes any disruption potentially very costly to the 3PL firm and its clients. The limited number of hubs utilized by the four major 3PL firms presents labor and social movements with a small number of key targets. The importance of economies of speed in transporting these high value cargoes means that manufacturers and customers depend on quick and reliable movement of cargoes to sustain just-in-time delivery and production systems, again making them vulnerable to disruption. As recently shown on a number of occasions, strikes such as those at the port of Hong Kong in 2013 (Gough 2013) can impose very high costs on 3PL firms and their clients, giving workers a significant amount of potential leverage to achieve improved wages and working conditions.

However, several qualifications are in order. The existence of four global firms and a number of smaller competitors provides shippers and customers with alternatives if only one firm's operations are disrupted. Government regulations prohibiting or constraining the 


\section{Journal of World-Systems Research}

organization of the logistics workforce in many Asian nations make labor organizing difficult in many locations. Further, the highly varied classifications of logistics workers, noted earlier, similarly constrain efforts to affect the operations of 3PL firms.

\section{Oil and Gas in North America: Deconstructing a Global Commodity Chain}

The stereotypical view of conventional oil and gas production is of drilling into the ground until an underground reservoir is punctured. The oil and/or gas in the reservoir is pushed up through the drill hole by the pressure of the rock and earth above the reservoir and of the stored oil and gas in the reservoir itself, with the image of the "gusher" on the surface representing successful exploration drilling. This view is reasonably accurate for many deposits of oil and gas, but oil sands and shale oil and gas are very different naturally-occurring forms of these raw materials that are referred to as "unconventional" deposits. Although oil sands and shale oil and gas ultimately feed into the same industrial and consumer uses as conventional petroleum, the natural characteristics of their deposits and the technologies used to extract these resources make them from the perspective of lengthened GCCs two distinct commodity chains within the global oil industry. The following two sections highlight a few of the key material characteristics of these two unconventional forms of oil that shape their use and their growing role in the North American and global oil and gas industries. We then look at the changing nature of the global oil and gas industry and the potential for North American "energy independence," which, if realized would deconstruct the currently global commodity chain in this industry via increased reliance on these two relatively new regionalized commodity chains. This trend may create significant new opportunities for labor in the sector, but the prospects for other political organizations, such as environmental groups, to affect this sector are less evident, as the current political debate over the Keystone XL pipeline for oil sands oil demonstrates.

\section{Canadian Oil Sands}

The best analogy for an oil sands deposit might be to describe it as an oily version of a peat bog. The oil is mixed in a layer of sand, clay and water with a consistency similar to tar; critics of the massive growth of the oil sands industry typically refer to this as "tar sands" because of the power of this image of a tarry sludge. The first challenge is to collect the oil sand, and the second is to separate the oil from the sand and other contaminants. The existence of these oil sands deposits in northern Alberta has been well known for more than a century, but finding ways to economically extract and process the oil into useful forms is a tremendous technological challenge. Proposed solutions to this challenge range from surface mining to exploding nuclear weapons underground to "cook" the oil sands and separate the oil using the heat and pressure from the nuclear explosion. The Canadian government and Canadian and international energy firms invested billions of dollars over the last several decades in search of economically competitive methods for extracting and separating the oil sands. The two most important solutions that were developed are large scale surface mining and in situ processing (Nikiforuk 2010; Marsden 2007; EIA 2012b).

Perhaps the single most important factor in transforming the Canadian oil sands from a heavily subsidized and globally uncompetitive curiosity in the 1970 s and 1980 s to a viable investment option for a rapidly growing number of the world's largest oil companies was the 
development of large scale truck and shovel mining technology in the British Columbian coal industry. These technological and organizational innovations reduced the cost and labor intensity of surface mining of coal dramatically in the 1980s and 1990s. Global coal oversupply, falling coal prices, and repeated rounds of restructurings and layoffs in the British Columbia coal mines made hundreds of skilled equipment operators available to the oil sands operations across the border in Alberta; these workers and the truck and shovel technologies and organizational operations were brought into the oil sands, leading to dramatic cost reductions. In combination with increased oil prices, the oil sands finally became globally competitive and thousands of acres of northern Alberta wetlands and forests were rapidly redefined as locations for oil production and the site of a boom in investment and extraction in this new link in the global oil commodity chain.

In situ extraction, typically used for deposits lying too far below the earth's surface to be removed in a cost effective manner via surface mining, uses large amounts of energy to heat water into steam that is pumped into the ground, which then carries the oil to the surface for collection and further refining. This energy-intensive process is typically powered by natural gas; a great deal of this raw material is needed to extract oil from these oil sands deposits. The use of relatively cleaner-burning natural gas to extract more highly polluting oil from the oil sands has been sharply criticized, but a rapidly growing number of these projects are being planned and built in northern Alberta (Nikiforuk 2010; Marsden 2007; EIA 2012b).

The "heavy" oil extracted from these deposits using either of these methods (surface mining or in situ extraction) requires further energy-intensive processing in upgraders located close to the deposits that heat and filter the oil sands oil to remove sand and other impurities, as well as a more complex refining process at the oil refinery itself than is necessary for oil from conventional deposits (termed "light, sweet crude"). Upgrader operations create a variety of formidable negative environmental impacts in the oil sands region, including air pollution, water pollution, and the release of a variety of toxic materials into the environment as part of the process of this initial stage of removing impurities, and these environmental impacts have been shown to cause a wide range of human health problems (Nikiforuk 2010; Marsden 2007; EIA 2012b).

The massive investments in these facilities and the resulting employment are also driving an economic boom, including high demand for labor and high wages, in the oil sands region. Workers in the oil sands industry have been able to earn very high wages in recent years because of the difficulty of attracting and retaining skilled workers in the remote areas of northern Alberta. Some workers, particularly those who maintain their permanent residences outside the oil sands region and fly or drive in for their work shifts, are able to use these high wages to fund a very comfortable lifestyle. However, other workers, including those providing services to the oil worker population, face a very high cost of living and serious social problems such as drug abuse and high crime rates in the Fort MacMurray region, and are thus benefiting much less from this booming generative sector. In short, the rapid growth associated with the exploitation of the oil sands creates a wide range of economic, social, and human health problems in the region (Nikiforuk 2010; Marsden 2007).

While the environmental impacts of the oil sands have become central concerns for national and international social movement organizations, the negative social and human health impacts have mainly been concerns for local community organizations and individual activists. Environmental groups, indigenous rights groups, and local citizens' organizations have had very limited success in challenging the dominance of the oil sands firms in the region, particularly in 


\section{Journal of World-Systems Research}

the context of the provincial government's longstanding support for the oil firms and the overriding goal of maintaining this booming industry. The remote, difficult to access extraction areas make it very challenging for activists from "outside" to have any leverage whatsoever over these physical sites - and the high worker wages and local business boom near the mines also make the prospect of "solidarity" between tar sands workers and many local residents, on the one hand, and environmentalists, on the other, even more unlikely.

Alberta has a great deal of refining capacity that was developed to serve the conventional oil production in the province during the 20th century. A rapidly growing share of the oil sands output is being refined outside the province, however, constraining the developmental benefits to the region from this production boom (Marsden 2007). Even after upgrading, oil from the oil sands does not flow well through pipelines. Oil sands producers bring in light crude via pipeline to mix with oil sands oil so that it will flow through pipelines to refineries in the United States or to ports on the Pacific Coast (Nikiforuk 2010; Marsden 2007; EIA 2012b), making this a highly unusual type of petroleum commodity chain. The proposed Keystone XL pipeline would transport oil sands oil to refineries on the U.S. Gulf Coast, but the future of this pipeline remains in question because of environmental and political opposition in the United States and Canada.

An alternative commodity chain for the oil sands has emerged during the uncertainty over the Keystone XL pipeline. Chinese firms are investing billions of dollars in the oil sands and pipeline firms, while the Canadian government is developing plans to both expand existing pipelines and construct new ones linking northern Alberta to the Pacific coast. This would, in effect, create an "alternative" commodity chain linking Canadian oil to China, the world's fastest growing petroleum market. China's rapid ascent over the last three decades and the resulting rapid growth in Chinese raw materials consumption and imports, and particularly of oil, have led many analysts to emphasize rivalry between China, the U.S., India, Japan and Europe for access to oil around the world. Some even predict a future of resource wars (Klare 2012, 2008, 2004, 2001; Moyo 2012; Hiscock 2012). The Keystone XL debate, regardless of its outcome, may simply help redirect the oil commodity chain to Canada, rather than slowing the rapid development of the oil sands, as environmental activists and organizations hope.

The U.S. Energy Information Agency (2012b) estimated oil sands reserves at 170 billion barrels of oil, $98 \%$ of Canada's total oil reserves. Total oil sands production increased from 114,000 cubic meters in 1967 , the first year of production, to 1.9 million cubic meters in 1970 , 8.0 million in 1980, 19.9 million in 1990, 35.4 million in 2000, and 92.5 million in 2011 (CAPP Table 3.2a). Canada is now the largest source of oil imports for the United States, virtually all from the oil sands. Canadian oil account for $25 \%$ of total U.S. imports, with 2.2 million barrels per day of crude oil flowing from Canada to the United States (EIA 2012b). Clearly, the oil sands have had a profound impact on U.S. oil supplies and reduced this country's dependence on distant and often volatile sources in the Middle East and elsewhere.

Although up to this point, the oil sands have been incorporated into a U.S.-focused commodity chain, this could change as the result of environmental opposition in the United States to consumption of this oil, given its disproportionate contribution to climate change. Many environmental groups have mobilized in opposition to the Keystone XL pipeline (including the Sierra Club, the Natural Resources Defense Council, the National Wildlife Federation, Greenpeace, and Friends of the Earth, among many others), organizing large scale protests against its construction in Washington (Strasser 2014), Chicago (Sobol 2013), and San Francisco (Lee 2013). The U.S. State Department's final environmental impact statement on the Keystone XL pipeline released in early 2014 concluded that there will be no significant negative impacts 
from the pipeline. Environmental organizations and the oil industry are pushing the Obama administration to issue a final decision on the project quickly, with environmental organizations increasing protest activity across the United States in February and March of 2014. Given the Obama administration's continued support for an "all of the above" energy strategy, the final decision is still uncertain. But as noted above, it is highly likely that the oil sands boom will continue, regardless of the decision reached in the United States. The only question is the ultimate destination of this commodity chain.

\section{North American Shale Oil and Gas}

Rather than accumulating in the reservoirs typical of most light, sweet crude oil and natural gas, shale oil and gas are contained in formations of shale rock. Shale oil and gas are unconventional because these deposits are "tight," meaning that the oil and gas do not easily flow out of the shale when a drill enters the deposit. Instead, oil producers drill into the shale formation and then use hydraulic fracturing ("fracking"), a mix of water and chemicals whose exact composition is protected as a trade secret, to break up the shale and free the oil and/or gas. Fracking has become a politically contentious issue in some parts of the United States because of the environmental and social impacts of this form of extraction, but the volumes of oil and natural gas being produced using this technology are growing rapidly. One key difference from oil sands oil is that the oil produced from shale is typically light, sweet crude that can be refined using conventional refining technology; shale natural gas is indistinguishable from natural gas from conventional deposits (EIA 2012a; DOE 2009).

The extraction of oil and gas from shale was technologically possible but uneconomic for many decades. One irony of the celebration of private investment in shale oil and gas during the 2012 presidential debates is that much of the technology that made this investment viable resulted from the partnership between the federal government and some oil and gas firms during the Carter Administration's efforts to promote energy independence during the $1970 \mathrm{~s}$. These innovations were utilized by first one and then by a growing number of firms to extract oil and gas from a shale formation in Texas; their pioneering efforts then became the model for the increasingly large scale boom now underway in other areas of the United States and increasingly around the world (EIA 2012a; DOE 2009).

U.S. shale gas reserves increased from 23,304 billion cubic feet in 2007 to 97,449 billion cubic feet in 2010 because of the boom in shale gas exploration, and production of shale gas increased from 1,293 billion cubic feet in 2007 to 5,336 billion cubic feet in $2010 .^{2}$ Shale oil reserves and production have undergone a similar but smaller scale boom. U.S. total imports of crude oil and oil products fell from 11.45 million barrels per day in 2008 to 7.8 million barrels per day in 2012 because of reduced demand and increased domestic production; U.S. shale oil production increased from 600,000 barrels per day in 2008 to 3.5 million barrels per day in early 2014 (The Economist Feb. 15, 2014). U.S. crude oil prices are now US\$10-20 per barrel below prices for the international benchmark Brent crude oil from the North Sea (Kingston 2012), evidence of the partial decoupling of the U.S. market from the global oil market.

The shale boom has brought a high demand for skilled labor and resulting high wages for workers in this industry. However, since the majority of labor demand is concentrated in the drilling phase of the industry and only a small number of workers are needed for ongoing

${ }^{2}$ US EIA, http://www.eia.gov/dnav/ng/ng enr shalegas a EPG0 R5302 Bef a.htm 


\section{Journal of World-Systems Research}

production, the industry relies largely on an itinerant labor force that works on drilling in an area for a few months and then moves on to the next area to be drilled. As a result, local businesses providing services to the industry experience a temporary boom but little sustained benefit or demand for local labor.

Many environmental organizations and local residents' groups have emerged in opposition to the shale oil and gas industry, ranging from national groups such as Greenpeace, Friends of the Earth and the Rainforest Action Network to dozens of local groups in at least 28 different states, and many have succeeded in securing substantial amounts of media attention. Unlike tar sands deposits, fracking sites are more dispersed and many are located close to homeowners and local environmental groups. This creates opportunities for picketing, blocking of access roads, etc. Recent examples of this sort of "direct action" activism include occupation of a site near Manchester, UK by several dozen camping protesters in early 2014 (Slater and Heward 2014) and an even larger protest in late 2013 by 400 Romanian villagers to block Chevron from installing the equipment for shale gas exploration in their community (Besliu 2013) - in both cases, large urban street protests supporting the anti-fracking activists followed.

In the United States, environmental activists, thus far, seem to prefer demonstrations urging politicians to oppose fracking, with the governors of both New York and California recent targets (Mehta and Finnegan 2014; Katz 2014). Yet we would argue that the potential for the sort of direct action/occupations seen elsewhere is present here because some characteristics of this industry seem to favor resistance by activist organizations, including the close proximity of producing and consuming regions within one nation's political boundaries, the use of pipelines to transport products, and the high degree of unionization along the commodity chain. However, other factors sharply constrain opposition to the industry, including the division of workers into a large number of distinct unions in the United States and Canada, the perceived geopolitical and economic value of North American energy independence, and a framing of this industry as a "jobs versus the environment" debate that creates significant cleavages between labor and environmental groups; these factors seem to be combining to overwhelm the opposition to this industry, despite its significant environmental and social costs and risks.

\section{Consequences of the Potential Reshaping and Disarticulation of the Oil Commodity Chain}

The oil industry and its commodity chains are longstanding examples of globalization, with changes in one area directly affecting all other regions (Yergin 2012); examples range from geopolitically created production shortfalls to natural disaster-caused disruptions of production and transport infrastructures to regulatory shifts that change relative costs and profitability, among many others. However, the growth of Canadian oil sands and North American shale oil and gas may serve to disrupt this global market by at least partially separating the North American market from the broader global market.

For the present analysis, the opportunity that the growing extraction and consumption of the oil sands and shale oil and gas in the United States presents for the decoupling of the North American and global energy markets is the first central issue. U.S. oil imports are falling and the United States may become an important exporter of oil products and of natural gas. The political rhetoric of North American energy independence may become a reality, making it possible for the United States to escape the need for competition and potential conflict over access to energy 
resources around the world. The existence of this opportunity does not guarantee that appropriate policies will be formulated and implemented. It simply means that a door is opening to fundamentally restructure U.S. resource access and hegemonic strategies in ways that could support a resurgence of U.S. economic competitiveness and potentially serve as the foundation for a new era of U.S. hegemony, much as the steamship and undersea telegraph opened the door for renewed British hegemony in the late nineteenth century.

For labor organizations, booms in oil sands and shale oil and gas production offer significant opportunities to organize rapidly growing numbers of workers in these sectors. There are various accounts of how well paid workers are, both in the Alberta tar sands project (Wood 2013) and in the "fracking"-led oil boom in North Dakota, where, according to Briody (2013) workers in the oil fields are earned an average annual wage of $\$ 112,462$ in 2012. Given current conditions, it may be much cheaper and less risky for firms to agree to relatively generous terms for labor in order to avoid delays and disruptions of construction and production during a period of high prices and high profits. Concessions to labor may even a good corporate strategy insofar as it underlines the "jobs versus the environment" framing of energy exploitation and discourages solidarity between labor and environmental activists.

Strong labor organizations already exist in some areas of this industry in the United States and Canada and they could potentially expand their membership and power in the current context. United States and Canadian labor unions have successfully worked together in the auto industry and may be able to do the same in the oil industry. There are, however, several constraints on this potential for labor, including the less favorable public view of unions in many parts of the U.S., the geographic dispersion of workers in the industry, and the very divergent skills and backgrounds of workers.

The potential reshaping and disarticulation of the global petroleum commodity chain created by the growth of the oil sands and shale oil and gas in North America present a mix of opportunities and constraints for environmental and community SMOs. On the positive side, concern over the negative environmental impacts of these resources has generated a great deal of public attention and debate and brought many new participants into SMOs opposing the growing use of these resources. However, the influence of SMOs at the local, national and international level up to this point has been relatively limited. U.S. and Canadian environmental groups, despite shared opposition to the growth of the oil sands, have not effectively coordinated their efforts. Geopolitical benefits of moving toward North American energy independence and maintaining China's rapid economic ascent and business interests in sustaining these booms and resulting high profits may trump these mobilization efforts.

\section{Comparing Opportunities and Constraints for Activists across Critical Commodity Chains}

In this article, we extend our previous analyses of a number of key historical and current episodes in which particular nodes of GCCs can become locations of conflict between capital, states, and labor and political organizations by applying this line of analysis to new economic sectors: the global logistics industry and oil and gas. We focus particular attention on the upstream stages of these GCCs and on the transportation links that are so critical to the long-term evolution of the capitalist world-economy. But what can be said by way of comparison? What similarities and contrasts can we observe within one commodity chain over time, and between different commodity chains in different industries, in terms of the opportunities for and 


\section{Journal of World-Systems Research}

constraints on labor and political organizing? And how do these comparisons allow us to examine the broader processes of social and environmental change?

We focused on two critical capitalist commodity chains, and it is this "criticality" that constitutes the key opportunity for labor and political movements in each of our examples. Each chain under consideration here is notable for its high degree of capital-intensity and global integration, and both are seen as key sectors to spur development and growth. The garment industry that fills thousands of containers every day and the oil industry both served as generative sectors in earlier periods, and governments in countries as diverse as Viet Nam, Pakistan, Azerbaijan, Nigeria, Canada and the United States all hope that these sectors can drive economic development today.

Major capital interests (multinational firms, backed by huge financial clout and supported by wealthy investors) dominate the global logistics industry, operating on a "just-in-time" basis that requires uninterrupted functioning, and as recent strikes and work stoppages demonstrate, these capital interests can experience significant losses due to effective labor and political organizing. For example, when Hong Kong dockworkers shut down terminals there, they were directly challenging the Hutchinson Whampoa group, controlled by billionaire Li Ka-shing (listed by Forbes as the $20^{\text {th }}$ richest person in the world with net assets of US\$ 31 billion) and costing his company over $\$ 640,000$ per day during the shutdown (McCafferty and Pang 2013). Logistics is based on rapid, seamless flows of goods, and this tends to create very high "stakes" for businesses and investors: this is why these commodity chains are potentially critical nodes for organizing.

Where oil and gas are concerned, the opportunities for organizing created by the characteristics of these critical commodity chains are enhanced by the interplay of economic, social, natural and environmental factors. The economic importance of oil and gas, coupled with the geopolitical considerations around potential North American energy independence, constitute a key vulnerability to be potentially harnessed by labor and political movements. Indeed, these factors and boom times in the oil and gas industries may make capital interests more likely to provide gains to labor as a means to minimize disruptions to the commodity chain.

If the importance or "criticality" of logistics and oil/gas tend to make them vulnerable to organizing at chokepoints, there are other factors that work against the sort of "disruption" that might lead to successful labor or political organizing. Three particular challenges stand out as obstacles to this sort of activism: issues of workforce variation and segregation; the availability of alternative nodes and networks and/or sources of supply in these chains; and the spatial articulation and disarticulation of the commodity chain.

First, the logistics and oil and gas sectors are both comprised of workforces that are spatially segregated, highly variegated and include large numbers of temporary workers. In the logistics industry, this is evident in the wide variety of logistics workers spread out over the globe, the distinct material conditions of their work realities, and the different legal classifications of workers that position some outside of the purview of traditional labor and community organizing efforts. For the oil and gas sector, this is a clear issue for shale oil and gas extraction, which largely relies on a small core workforce supported by a greater number of transient workers spread out over a wide geography.

Organizing such diffuse groups of workers presents an immense challenge. How can such varied groups of workers, separated by job types, legal classifications and geography, become unified in an organized struggle against the interests of capital? Though the contours of the workforces in both commodity chains examined here prevent simple conclusions from being 
drawn where activism efforts are concerned, recent developments in the logistics sector may offer evidence for some cautious optimism. Port truck drivers and warehouse workers, two segments of the logistics workforce whose classification as independent contractors and temporary workers poses significant challenges to labor organizing, have not only been actively participating in organizing efforts; they have also achieved some successes. Certain groups of port truck drivers in Southern California recently won legal victories that overturn their "misclassification" as independent contractors, paving the way for them to pursue labor organizing campaigns. For instance, truck drivers at the twin ports of Long Beach and Los Angeles employed by the company Toll Group now boast the first union contract among Southern California port truck drivers in decades (Coalition for Clean \& Safe Ports 2013b). Critically, Toll Group is an Australian logistics company, and truck drivers in Australia provided vocal support for the organizing efforts of their Southern California counterparts (Coalition for Clean \& Safe Ports 2013a), demonstrating a nascent potential for global connections even among workers separated by distance and constrained by legal classifications of their work.

Similarly, recent organizing efforts among warehouse workers, particularly temporary employees working at Wal-Mart, offer some evidence that the challenges posed by workforce composition and organization can potentially be overcome in the logistics sector. Capitalizing on critical moments in the race to capture consumer spending during the holiday shopping season, Wal-Mart workers staged protests around "Black Friday" shopping in recent years. Importantly, these protests were spread widely across geographical areas, within and even outside of the US, as well as across different groups of Wal-Mart workers, including those who work in retail stores as well as distribution centers (Eidelson 2013). Again, the widespread coordination of these efforts across differentiated groups of workers is an encouraging sign. Indeed, in the case of the 2013 Wal-Mart pre-holiday action, it is also significant to note that consumers and various social movement groups (including environmental organizations) also supported the workers' protests (Dreier 2013). This is exactly the sort of coordinated effort that leading scholars of global commodity chains suggest are necessary to bring about real change (Appelbaum 2005). However, as promising as this may be, it is important to recognize that, at present, successful efforts like these remain the exception in logistics, rather than the rule.

Another key issue that constitutes a challenge to labor and political organizing across commodity chains is the existence of alternatives that could undermine the impact of commodity chain disruption. In logistics, this occurs in the form of competing 3PL providers that clients can turn to, while in the case of the Canadian oil sands, activists have to confront the possibility that other geopolitical rivals will be willing consume the oil if the United States does not. The rationale behind organizing in commodity chains such as these is to cause a significantly largescale disruption that capital will acquiesce to the demands of labor, environmental, or other community groups. But in both cases, the ability of the commodity chain to continue functioning via alternate avenues limits the extent and impact of the leverage that labor and political organizing efforts can wield. Successful organizing efforts in both arenas will require making a dent in the bottom-line profit of capital. Certainly, the "stakes" in each commodity chain are high, as discussed previously, and yet the existence of alternate pathways through which disruptions can be circumvented present significant difficulties for organizing interests.

While the joint action by Occupy protesters and port workers on the west coast in 2011 or the "turtles and teamsters" alliance in the protests at the WTO meeting at Seattle over a decade earlier (Cooper 1999) - might suggest that labor and other types of social movements have a high potential for collaborating to disrupt critical nodes in worldwide commodity chains, 


\section{Journal of World-Systems Research}

it is important to note that this is not always the case. Obviously, oil and gas workers, particularly if they are well-compensated, may have a strong interest in continuing, or even intensifying, production, whether that be in Fort McMurray, Alberta, a local "fracking" site, or in a greenfield area targeted for construction of new pipelines. In these cases, the interests of labor and capital may rather closely coincide, but be diametrically opposed to social movements that want to slow or stop extraction and transport of fossil fuels. This exemplifies the "jobs versus environment" framing, which, while clearly a trope favored by corporations and investors, may be a real impediment to any real solidarity between workers and environmental activists. One can also imagine various social justice mobilizations to disrupt logistics networks (perhaps over poor labor conditions in outsourced manufacturing, environmentally degrading products/production processes, or violations of human rights overseas) that might not be supported by dockworkers or employees of 3PL firms. Indeed, we know from an abundant scholarship on social movements that we cannot assume that various progressive forces are automatically aligned (e.g. Clawson 2003).

Further, the disarticulation of commodity chains (which may be even more pronounced in the case of sectors like coal or iron ore, and the textile/garment industry, as well as major port complexes) is yet another challenge for organizing efforts. In the two cases we consider, observing contrasts within commodity chains over time provides a particularly illuminating view of how articulation and disarticulation provide different settings for labor and political organizing. Other historical examples similarly highlight the impacts of articulation and disarticulation. Bair and Warner (2011) document the disarticulation of one region of Mexico from the garment GCC and the severe impacts on labor and capital in that region. Some leaders of "petro states" in the Middle East already express concern about the impacts of declining U.S. oil imports from their region because of increased shale oil production (Evans-Pritchard 2013) and BP projects that North America will reach energy self-sufficiency in 2018 (Lawler and Eisenhammer 2014). Complete disarticulation of the United States from the Middle Eastcentered oil commodity chain could be similarly disastrous for labor and capital in that region. In one of the most rapid and complete processes of disarticulation from a GCC, the rubber "bust" in the Brazilian Amazon in the early 20th century (Bunker 1985), local labor, capital and the natural environment were rapidly devalued and labor had no opportunity to organize to even earn a survival wage.

Our focus on lengthened commodity chains and how they affect labor and other groups in particular places and times allows us to analyze both opportunities (such as high wages for oil sands and dockworkers in some times and places) and constraints (e.g. the "China alternative" to the Keystone XL pipeline that may render opposition in the United States ineffective in stopping the expanding production of oil from the oil sands) on labor and social movement organizations.

\section{Conclusion}

The recent efforts by the Occupy movement to disrupt traffic through West Coast ports in the United States provided a dramatic and timely illustration of labor's attempt, in alliance with wider civil society protests, to exert power over leading firms in the world economy. Some contemporary commentators dismissed the entire wave of "Occupy" activism in the United States in 2011 as transient and inconsequential (cf. Sorkin 2012). Perhaps. But framed in terms of the larger crisis of global capitalism, and seen for the worldwide phenomenon it was, Occupy was a world anti-systemic movement, a reaction not only to the short-term effects of the "Great 
Recession" of 2009-2010 but also a cumulative popular response to decades of neo-liberal attacks on working people and the middle class in core countries (Macpherson and Smith 2013). If that argument is correct, the "Occupy" moniker may pass from use, but the new core "precariat" saddled with enormous personal debts and increasing job insecurity may continue to pursue these seemingly less institutionalized and more "horizontalist" ways to resist. If that is the case, the "disruption" of transportation systems "choke points" (at ports and elsewhere) could be a crucial tactic of resistance to corporate dominance in the coming decades, as global capitalism experiences the trauma of 'the age of transition' (Wallerstein 2000). The more recent Hong Kong dock workers strike, in which a small number of workers, with solidarity from local students and political leaders, halted traffic for days at the world's third busiest port, shows that there is a genuine vulnerability to this sort of action at major global transportation nodes.

Our paper is not attempting to formally dialogue with the extensive literature on the sociology of social movements, but it does seem like a broad-based "Occupy-like" mobilization might help unify various anti-systemic forces; this, in turn, could make insurgent exploitation of "long," integrated and critically important commodity chains, like the ones discussed here, more vulnerable to labor or activist disruption. Some sort of loosely confederated anti-neoliberal mobilization that could unify a variety of groups and actors in common resistance to a target as amorphous as contemporary "global capitalism," in fact, might be a much more promising way to take on corporate power and its state-based allies than the currently anemic forces of "left" political parties or labor unions (Macpherson and Smith 2013). Though these efforts recall previous attempts of labor throughout history, the Occupy endeavors raise an important question about whether or not the contemporary moment is one where labor and other progressive forces can unite to capitalize on opportunities to interrupt flows of commerce at key nodal points of extraction, processing, or transportation. Our examination highlights those opportunities and constraints for labor and other social movement organizations across two critical commodity chains: the global logistics industry and oil and gas in North America.

In each case, we find vulnerabilities on which labor and social movement organizations could capitalize, usually stemming from the capital intensiveness and global integration of each critical commodity chain. In the case of Canadian oil sands, the potential decoupling of the U.S. and global energy markets, which could lead to North American energy independence, stands out as a particular vulnerability that could be harnessed by labor movements. However, our analysis also shows constraints on labor and social movement organizing in each critical commodity chain. In the logistics sector, for instance, this stems from the varied composition and spatial segregation of components of the logistics workforce. Our analysis suggests that while transport and raw materials remain vulnerable nodes in capitalist commodity chains, there are also constraints and challenges to be faced by labor and social movement organizations trying to leverage those linkages. Although transport and raw materials continue to be vital sectors for labor organizing, the particular configurations of political and economic power within each sector demands careful consideration.

Our article provides a detailed assessment of two sectors - the global logistics industry and Canadian oil sands/North American "fracking" - as sites for potential advances by labor and other activists (with the important proviso that these two groups may not always be "on the same page" politically). But we are also aware that other sectors present much more daunting difficulties for this sort of organizing. Future research in this area should examine contemporary organizing efforts in other sectors to determine under what conditions labor and various movement activists are able to exert power. Specifically, light industrial manufacturing, various 


\section{Journal of World-Systems Research}

types of mining, and international petroleum shipping are GCCs that present steeper challenges to labor and other groups eager to "disrupt" the global flows and win concessions from capital. But doubtless there are other industries that are either more vulnerable, or more insulated from this sort of organizing, in the world economy today. Future research might focus on potential vulnerabilities in other sectors, such as business, tourism, and travel, rare earths, or other manufacturing sectors dependent on global production and transport networks.

\section{References}

Anderson, Edward, Tim Coltman, Timothy Devinney, and Bryan Keating. 2011. "What Drives the Choice of a Third-Party Logistics Provider?" Journal of Supply Chain Management 47(2):97-115.

Appelbaum, Richard, David Smith, and Brad Christerson. 1994. "Commodity Chains in the Pacific Rim: Garment Trade and Manufacturing." Pp. 187-204 in Commodity Chains and Global Capitalism, edited by G. Gereffi and M. Korzeniewicz. Westport, CT: Praeger.

Appelbaum, Richard. 2005. "Fighting Sweatshops: Problems of Enforcing Global Standards." Pp. 369-378 in Critical Globalization Studies, edited by R. Appelbaum and W. Robinson. New York: Routledge.

Arrighi, Giovanni. 1994. The Long Twentieth Century: Money, Power, and the Origins of Our Times. London: Verso.

Bair, Jennifer. 2005. "Global Capitalism and Commodity Chains: Looking Back, Going Forward." Competition and Change:9(2):153-180. . 2009. "Global Commodity Chains: Genealogy and Review." Pp. 1-34 in Frontiers of Commodity Chain Research, edited by J. Bair. Stanford, CA: Stanford University.

Bair, Jennifer and Gary Gereffi. 2001. "Local Clusters in Global Chains: The Causes and Consequences of Export Dynamism in Torreon's Blue Jeans Industry." World Development 29(11):1885-1903.

Bair, Jennifer and Marion Werner. 2011. "The Place of Disarticulations: Global Commodity Production in La Laguna, Mexico." Environment and Planning A: 43:998-1015.

Besliu, Raluca. 2013. "Pungesti: Romania's Battlefield Against Chevron: Romanian Villagers Struggle to Protext Their Land and Environment from Fracking." Al-Jazeera (online), December 13: http://www.aljazeera.com/indepth/opinion/2013/12/pungesti-romaniabattlefield-against-chevron-201312117349323363.html.

Bhatnager, Rohit and S. Viswanathan. 2000. "Re-Engineering Global Supply Chains: Alliances Between Manufacturing Firms and Global Logistics Services Providers." International Journal of Physical Distribution \& Logistics Management: 30(1):13-34.

Bonacich, Edna and Juan Carlos De Lara. 2009. "Economic Crisis and the Logistics Industry: Financial Insecurity for Warehouse Workers in the Inland Empire." UC Los Angeles: Institute for Research on Labor and Employment. Retrieved from: http://escholarship.org/uc/item/8rn2h9ch.

Bonacich, Edna and Jake Wilson. 2008. Getting the Goods: Ports, Labor and the Logistic Revolution. Ithaca, NY: Cornell University.

Bunker, Stephen G. 1985. Underdeveloping the Amazon. Chicago: University of Chicago Press. 
Bunker, Stephen G. and Paul S. Ciccantell. 2005. Globalization and the Race for Resources. Baltimore: Johns Hopkins University Press. 2007. An East Asian World Economy: Japan's Ascent, with Implications for China. Baltimore, MD: Johns Hopkins University Press.

Ciccantell, Paul S., David A. Smith, and Elizabeth A. Sowers. 2012. "Are Transport and Raw Materials Still Vulnerable Nodes in Capitalist Commodity Chains?" Paper presented at the $36^{\text {th }}$ annual Political Economy of the World System (PEWS) conference of the American Sociological Association. Worcester, MA. April 2012.

Chase-Dunn, Christopher. 1989. Global Formation: Structures of the World-Economy. Cambridge: Basil Blackwell.

Ciccantell, Paul. 2009. "China's Economic Ascent Via Stealing Japan's Raw Materials Peripheries." Pp. 109-129 in China and the Transformation of Global Capitalism, edited by H. Hung. Baltimore, MD: Johns Hopkins University Press.

Clawson, Dan. 2003. The Next Upsurge: Labor and the New Social Movements. Ithaca, NY: Cornell University Press.

Coalition for Clean \& Safe Ports. 2013a. "Truck Drivers Clinch New Power with First Union Contract at L.A. Ports." January 9, 2013. Available: http://cleanandsafeports.org/blog/2013/01/09/truck-drivers-clinch-new-power-with-firstunion-contract-at-1-a-ports/ Accessed: February 15, 2014.

2013b. "Clean Ports Act of 2013 Introduced to Empower Local Ports to Reduce Environmental Pollution, Mitigate Traffic Congestion, and Improve Highway Safety." August 1, 2013. Available: http://cleanandsafeports.org/blog/2013/08/01/clean-ports-actof-2013-introduced-to-empower-local-ports-to-reduce-environmental-pollution-mitigatetraffic-congestion-improve-highway-safety/ Accessed: February 15, 2014.

Cooper, Marc. 1999. "Teamsters and Turtles: They're Together at Last." Los Angeles Times, December 2.

Cudahy, Brian J. 2006. Box Boats: How Container Ships Changed the World. New York: Fordham University Press.

Deffeyes, Kenneth. 2005. Beyond Oil: The View from Hubbert's Peak. New York: Hill and Wang.

U.S. Department of Energy (DOE). 2009. Modern Shale Gas in the United States: A Primer. Washington, DC: US DOE.

Davies, Paul J. and Josh Noble. 2013. "Hong Kong Dockers Accept Pay Raise and End Strike Action." Financial Times, May 7.

Donovan, Arthur and Joseph Bonney. 2006. The Box that Changed the World: Fifty Years of Container Shipping. East Windsor, NJ: Commonwealth Business Media.

Dreier, Peter. 2013. "Walmart Workers Will Make History on Friday as America Confronts Growing Inequality." Huffington Post, September 26.

Economist, The. 2014. "Saudi America: The Economics of Shale Oil." The Economist, Feb. 15, 2014.

Eidelson, Josh. 2013. "Wal-Mart Workers Plan 'Widespread, Massive Strikes and Protests' for Black Friday 2013." The Nation, Spetember 6, 2013. Available at http://www.thenation.com/blog/176054/walmart-workers-plan-widespread-massive strikes-and-protests-black-friday-2013\# Accessed: February 15, 2014.

U.S. Energy Information Agency (EIA). 2012a. What Is Shale Gas and Why Is It Important? Washington, DC: US DOE. 


\section{Journal of World-Systems Research}

.2012b. Canada Country Analysis Brief. Washington, DC: US DOE.

Evans-Pritchard, Ambrose. 2013. "U.S. Shale Threatens Saudi Funding Crisis and Demise of OPEC." Available at http://www.telegraph.co.uk/finance/newsbysector/energy/oilandgas/10209822/US-shale-threatens-Saudi-funding-crisis-and-demise-ofOPEC.html.

Gereffi, Gary. 1994. 'The Organization of Buyer-Driven Global Commodity Chains: How U.S. Retailers Shape Overseas Production Networks." Pp. 95-122 in Commodity Chains and Global Capitalism, edited by G. Gereffi and M. Korzeniewicz. Westport, CT: Praeger.

Gereffi, Gary and Miguel Korzeniewicz, eds. 1994. Commodity Chains and Global Capitalism. Westport, CT: Praeger.

Gereffi, Gary, Miguel Korzeniewicz, and Roberto Korzeniewicz. 1994. "Introduction: Global Commodity Chains." Pp. 1-14 in Commodity Chains and Global Capitalism, edited by G. Gereffi and M. Korzeniewicz. Westport, CT: Praeger.

Gereffi, Gary and Olga Memdovic. 2003. The Global Apparel Value Chain: What Prospects for Upgrading by Developing Countries? Vienna, Austria: United Nations Industrial Development Organization.

Gough, Neil. 2013. "Hong Kong Strike Clogs Shipping Traffic." New York Times, April 3, 2013.

Hertz, Susanne and Monica Alfredsson. 2003. "Strategic Development of Third Party Logistics Providers." Industrial Marketing Management 32:139-149.

Hopkins, Terence and Immanuel Wallerstein. 1982. World-Systems Analysis: Theory and Methodology. Beverly Hills, CA: Sage.

ISO. 2006. Environmental Management - Life Cycle Assessment - Principles and Framework. Geneva: International Organization for Standardization.

Katz, Celeste. 2014. "Hydrofracking Foes Vow to Dog Gov. Cuomo at Manhattan Re-election Campaign Stop." New York Daily News http://www.nydailynews.com/blogs/dailypolitics/2014/01/hydrofracking-foes-vow-todog-gov-cuomo-at-manhattan-re-election-campaign-stop

Kingston, John. 2012. "Breaking Dependency." Platt's Insight, December: 4-9.

Klare, Michael. 2001. Resource Wars: The New Landscape of Global Conflict. New York: Metropolitan Books.

. 2004. Blood and Oil: The Dangers and Consequences of America's Growing Dependency on Imported Petroleum. New York: Metropolitan Books. . 2008. Rising Powers, Shrinking Planet: The New Geopolitics of Energy. New York: Metropolitan Books. . 2012. The Race for What's Left: The Global Scramble for the World's Last Resources. New York: Metropolitan Books.

Klaus, Peter. 2011. "The Assessment of Competitive Intensity in Logistics Markets." Logistics Research 3: 49-65.

Lawler, Alex and Stephen Eisenhammer. 2014. "Middle East Faces Challenges from Shale and Within-BP." idUKBREA0E1B820140115. http://uk.reuters.com/article/2014/01/15/uk-bp-energy-

Lee, Stephanie M. 2013. "Thousands Protest Keystone XL Pipeline." SFGate (online): http://www.sfgate.com/science/article/Thousands-protest-Keystone-XL-pipeline4286432.php

Levinson, Marc. 2006. The Box: How the Shipping Container Made the World Smaller and the World Economy Bigger. Princeton, NJ: Princeton University Press. 
Lobo, Ingrid and Mohamed Zairi. 1999a. "Competitive Benchmarking in the Air Cargo Industry: Part I." Benchmarking 6(2):164-190.

. 1999b. "Competitive Benchmarking in the Air Cargo Industry: Part II." Benchmarking 6(3):220-238. . 1999c. "Competitive Benchmarking in the Air Cargo Industry: Part III." Benchmarking 6(4):302-309.

Macpherson, Robert and David A. Smith. "Occupy as a World Anti-Systemic Movement." Peace Review 25:367-375.

Marsden, William. 2007. Stupid to the Last Drop: How Alberta is Bringing Environmental Armageddon to Canada (and Doesn't Seem to Care). Toronto: Knopf Canada.

McCafferty, Georgia and Esther Pang. 2013. "Hong Kong Dock Strike Cripples World's Third Busiest Port." CNN (on line), April 4: http://www.cnn.com/2013/04/03/world/asia/hongkong-dock-strike/.

Mehta, Seema and Michael Finnegan. 2014, "Fracking Foes Make a Racket as Brown Addresses California Democrats." Los Angeles Times, http://www.latimes.com/local/political/la-mepc-california-democrats-jerry-brown-fracking20140308,0,650299.story\#axzz2vssXviSG.

Monaco, Kristen and Kimberly Ritter. 2009. "Employment and Earnings in Southern California Trade-Dependent Industries." Final Report Metrans Project 08-17.

Moyo, Dambisa. 2012. Winner Take All: China's Race for Resources and What it Means for the World. New York: Basic Books.

O'Hearn, Denis. 2001. The Atlantic Economy: Britain, the US and Ireland. Manchester: Manchester University Press.

O'Riain, Sean. 2004. "The Politics of Mobility in Technology-Driven Commodity Chains: Developmental Coalitions in the Irish Software Industry." International Journal of Urban and Regional Research 28(3):1203-1212.

Schrank, Andrew. 2004. "Ready-To-Wear Development: Foreign Investment, Technology Transfer, and Learning-by-Watching in the Apparel Trade." Social Forces 83(1):123156.

Selvin, David. 1996. A Terrible Anger: The 1934 Waterfront and General Strikes in San Francisco. Detroit, MI: Wayne State University Press.

Sheffi, Yossi. 2012. "Driving Growth and Employment Through Logistics." MIT Sloan Management Review 54(1):20-22.

Simmons, Matthew. 2005. Twilight in the Desert: The Coming Saudi Oil Shock and the World Economy. Hoboken, NJ: John Wiley \& Sons.

Slater, Chris and Emily Heward. 2014. "Barton Moss Anti-Fracking Protesters Celebrate LastMinute Reprieve." Manchester Evening News, March 11. http://www.manchestereveningnews.co.uk/news/greater-manchester-news/videopictures-barton-moss-anti-fracking-6799433.

Sobol, Rosemary R. 2013. "22 Arrested During Keystone Protest." Chicago Tribune (accessed online): $\quad \underline{\text { http://articles.chicagotribune.com/2013-06-17/news/chi-keystone-pipeline- }}$ protest-arrests-chicago 1 keystone-xl-xl-pipeline-chicago-police

Sorkin, Andrew Ross and Jad Mouawad. 2005. "Bid by Chevron in Big Oil Deal Thwarts China." New York Times, July 20.

Sorkin, Andrew Ross. 2012. "Occupy Wall Street: A Frenzy that Fizzled." New York Times, September 17. 


\section{Journal of World-Systems Research}

Strasser, Annie-Rose. 2014. "Hundreds Arrested in Protest of Keystone XL Pipeline." Climate Progress (online): http://thinkprogress.org/climate/2014/03/02/3350081/photos-keystoneprotest-arrests/\#.

Taylor, Michael and Alan Hallsworth. 2000. "Power Relations and Market Transformation in the Transport Sector: The Example of the Courier Services Industry." Journal of Transport Geography 8:237-247.

Wallerstein, Immanuel. 1974. The Modern World-System. New York: Academic Press. . 2000. "Globalization or the Age of Transition? A Long-Term View of the Trajectory of the World-System." International Sociology 15(2):249-265.

Wood, Linda S. 2013. "Hard Work, High Pay in Tar Sands "Hell." Vancouver Observer, July 9. Online access: http://www.vancouverobserver.com/environment/hard-work-high-pay-tarsands-hell.

Yergin, Daniel. 2012. The Quest: Energy, Security, and the Remaking of the Modern World. New York, NY: Penguin Books. 